\title{
Edukasi Literasi Media Digital Kepada Pengurus OSIS SMA Nasional Malang Untuk Pencegahan Cyberbullying di Masa Pandemi
}

\author{
Prawinda Putri Anzari*1, Desy Santi Rozakiyah², Seli Septiana Pratiwi ${ }^{3}$ \\ 123Program Studi Pendidikan Sosiologi, Fakultas Ilmu Sosial, Universitas Negeri Malang \\ *e-mail: prawinda.anzari.fis@um.ac.id¹, desy.rozakiyah.fis@um.ac.id²,seli.pratiwi.fis@um.ac.id³
}

\begin{abstract}
Abstrak
Kegiatan Belajar Dari Rumah di masa pandemic Covid-19 membuat para pelajar menghabiskan waktu lebih banyak di depan perangkat teknologi dan internet. Semakin banyak waktu yang dihabiskan di internet, maka semakin besar kemungkinan para pelajar menjadi pelaku maupun korban cyberbullying. Cyberbullying biasanya terjadi karena pengguna internet tidak paham bagaimana tetap membuat diri mereka aman serta kurang memahami etika bermedia sosial yang baik. Hal ini juga dirasakan oleh para pelajar di kota Malang, khususnya SMA Nasional Kota Malang. Tujuan dari abdimas ini adalah untuk memberikan pengetahuan serta pemahaman kepada Pengurus OSIS SMA Nasional mengenai Literasi Media Digital. Metode yang digunakan dalam pengabdian ini adalah penyuluhan berupa pemberian materi mengenai cyberbullying dan etika bermedia sosial. Hasil dari pengabdian ini adalah para pengurus OSIS SMA Nasional Kota Malang memiliki pengetahuan mengenai pencegahan cyberbullying dan literasi bermedia sosial, serta para guru SMA Nasional juga memahami bahwa guru di sekolah memiliki peran penting dalam pencegahan kasus cyberbullying.
\end{abstract}

Kata kunci: cyberbullying, literasi media, media digital, media sosial

\section{PENDAHULUAN}

Pada tanggal 18 Mei 2020 Kementrian Pendidikan dan Kebudayaan secara resmi mengeluarkan Surat Edaran Nomor 15 Tahun 2020 tentang Pedoman Penyelanggaraan Belajar Dari Rumah Dalam Masa Darurat Penyebaran Covid-19. Tujuan dari dilaksanakannya Belajar Dari Rumah (BDR) adalah memastikan pemenuhan hak peserta didik untuk mendapatkan layanan pendidikan selama darurat Covid-19, melindungi warga satuan pendidikan dari dampak buruk Covid-19, mencegah penyebaran dan penularan Covid-19 di satuan pendidikan dan memastikan pemenuhan dukungan psikososial bagi pendidik, peserta didik, dan orang tua. Kemendikbud memberikan dua pilihan pendekatan BDR yaitu pembelajaran jarak jauh dalam jaringan (daring) dan luar jaringan (luring).

Seperti yang terlihat di beberapa kota besar termasuk di Malang sendiri, kegiatan BDR hampir seluruhnya dilaksanakan secara daring terukur dari tingkat TK hingga SMA. Dengan berjalannya kegiatan BDR secara daring ini, tak dapat dipungkiri hal ini membuat pelajar lebih banyak menghabiskan banyak waktunya di Internet. Peraturan PSBB di di Kota Malang yang membatasi kegiatan di luar rumah juga membuat orangtua merasa lebih aman membiarkan anaknya bermain internet maupun media sosial di rumah ketimbang berada di ruang publik. Terlebih lagi saat ini banyak pelajar dari bangku hingga SD dan SMA yang merupakan digital native sehingga tidak memerlukan pendampingan karena mereka mampu mengoperasikan perangkat teknologi komunikasi secara mandiri.

Dengan durasi penggunaan internet yang meningkat, terdapat kekhawatiran baru yang muncul karena anak-anak akan lebih rawan terdampak kasus cyberbullying atau perundungan melalui media social. Salah satu penyebab terjadinya peningkatan cyberbullying kepada anakanak adalaah adanya kebosanan karena kegiatan yang terbatas, kurangnya literasi digital, dan stress yang meningkat. Seperti yang diungkapkan Doree Bogdan Martin, direktur International Telecommunication Union (ITU) bahwa pelajar yang mengakses internet di usia dini dan menghabiskan waktu yang lama di internet memiliki peluang yang sangat besar akan terjadinya cyberbullying karena mereka terus menerus berada di rumah ketika pandemi (Farge, 2020) 
Berdasarkan hasil survey Asosiasi Penyelengara Jasa Internet Indonesia (APJII) pada tahun 2018, presentase pengguna internet paling besar adalah remaja dengan usia 15 hingga 19 yang menduduki peringkat sebanyak 91\%. Meskipun presentase pengguna internet di Indonesia termasuk tinggi, namun pengguna internet adalah pengguna yang pasif karena mereka hanya pengguna yang konsumtif terhadap aplikasi-aplikasi yang ditawarkan oleh teknologi digital tanpa pendayaan teknologi digital dengan optimal (Candrasari \& Claretta, 2020). Periode remaja dalam rentang usia tersebut rentan dengan berbagai perilaku penyimpangan dan kenakalan, salah satunya adalah perilaku bullying. Bullying dapat terjadi karena adanya kekuatan yang tidak seimbang. Dalam suatu kejadian bullying, terdapat tiga unsur utama yang terlibat yaitu pelaku atau penindas, korban atau tertindas, dan penonton atau orang yang tidak terlibat secara langsung tapi turut menyaksikan kejadian tersebut. (Malihah \& Alfiasari, 2018). Hampir sama seperti bullying yang melibatkan proses face to face, cyberbullying sendiri merupakan suatu tindakan agresif yang menyebabkan terkucilnya mental korban hingga kesusahan. Cyberbullying ditandai dengan perilaku yang berulang dan terjadi antara individu yang hubungannya ditandai oleh ketidakseimbangan kekuatan (Whittaker \& Kowalski, 2015).

Perilaku yang dapat diindentifikasi sebagai kegiatan cyberbullying yang kerap terjadi di kalangan pelajar dapat berupa menolak seorang temannya bergabung dalam aplikasi chatting maupun game online, meninggalkan komentar negatif pada unggahan seseorang di media sosial, menyebarkan gosip melalui media sosial maupun email, hingga menyebarkan foto maupun video yang memalukan atau intim tanpa persetujuan pemiliknya.

Hal yang menyebabkan perundungan maya bagi pelajar di masa pandemi menjadi masalah yang serius karena pada perundungan tradisional, biasanya terjadi pada waktu jam sekolah, sementara cyberbullying ini dapat terjadi selama 24 jam. Para pelajar yang melakukan pembelajaran di rumah dapat menjadi korban kapan saja dan di mana saja. Ia dapat dirundung oleh temannya setelah jam sekolah berakhir (Sartana \& Afriyeni, 2017). Termasuk ketika mereka berada di tempat aman yaitu di rumah dan di tengah-tengah keluarga mereka.

Berdasarkan kondisi dan latar belakang tersebut, maka Tim Abdimas dari Prodi Pendidikan Sosiologi, Fakultas Ilmu Sosial, Universitas Negeri Malang memutuskan untuk melakukan pengabdian kepada pelajar di SMA Nasional Malang. Pengabdian yang diberikan adalah edukasi mengenai literasi digital serta etika bermedia sosial untuk mencegah terjadinya cyberbullying di masa pandemi. Tim pengabdian meyakini literasi digital sangat dibutuhkan oleh pelajar saat ini serta dapat meminimalisisr terjadinya cyberbullying. Literasi media digital merupakan kemampuan, pengetahuan, kesadaran, dan keterampilan secara khusus kepada khalayak sebagai pengonsumsi media informasi yang terhubung atau terkoneksi dengan internet dan penggunaan smartphone. (Kurniawati \& Baroroh, 2016)

Tujuan dari kegiatan pengabdian ini adalah pencegahan adanya korban maupun pelaku tindakan cyberbullying, mengingat kebijakan yang diturunkan oleh Kemendikbud di masa pandemi membuat pelajar semakin banyak menggunakan waktu mereka dengan perangkat teknologi dan internet. Kebutuhan pelajar akan media digital mulai menjadi sebuah kebutuhan primer, dan alangkah baiknya apabila mereka dapat berkarya di internet dengan aman tanpa kekhawatiran menjadi korban maupun pelaku dari cyberbullying.

\section{METODE}

Kegiatan pengabdian di SMA Nasional Malang dilaksanakan pada bulan Juli 2020. Metode penyuluhan dipilih dalam kegiatan pengabdian ini untuk meningkatkan pengetahuan siswa SMA nasional Malang mengenai cara beretika bermedia sosial untuk pencegahan terjadinya cyberbullying di masa pembelajaran dari rumah. Mitra yang mengikuti kegiatan pengabdian ini adalah pengurus OSIS SMA Nasional Malang yang berjumlah 20 orang.

Menggunakan metode penyuluhan, para pengurus OSIS SMA Nasional Malang dibekali pengetahuan dasar mengenai perilaku yang termasuk dalam kategori cyberbullying, dampak dari 
cyberbullying, komponen literasi digital yang harus dimiliki anak muda di abad ke-21, serta bagaimana cara berpikir kritis dalam menggunakan media sosial. Tahap pertama dalam penyuluhan dimulai dengan melakukan pengurusan perizinan kepada pihak SMA Nasional Malang serta survey dan observasi. Survey dan observasi dilakukan sebagai langkah awal dalam penelitian untuk mengetahui secara jelas tentang objek penelitian/sasaran (Dipo \& Samsudin, 2016).

Tahap selanjutya adalah tim pengabdian mempersiapkan materi. Materi yang disiapkan berupa papan materi dalam bentuk power point, serta materi dalam bentuk buku saku. Selain menyiapkan materi, tim pengabdian juga mempersiapkan kebutuhan lainnya yang bersifat administratif. Tahap kedua adalah pelaksanaan penyuluhan kepada Mitra berdasarkan jadwal yang telah disepakati. Kegiatan penyuluhan dibagi dalam tiga tahap. Tahap pertama adalah pre test yang bertujuan untuk mengetahui sejauh mana tingkat penggunaan teknologi para pengurus OSIS SMA Nasional Malang, serta apakah mereka telah memahami etika bermedia sosial, serta apa saja perilaku cyberbullying yang mereka pahami. Pemberian materi dibagi dalam dua tahap. Tahap pertama adalah penjelasan mengenai perilaku bullying, tahap kedua adalah penjelasan mengenai etika bermedia sosial serta pentingnya berpikir kritis ketika menggunakan internet. Kegiatan ketiga adalah evaluasi yang dilakukan dengan memberikan post-test kepada peserta. Post test dilakukan untuk mengetahui sejauh mana pemahaman peserta pengabdian dengan penyuluhan yang telah diberikan.

Tahap ketiga adalah evaluasi kegiatan serta pembagian buku saku kepada pengurus OSIS SMA Nasional Malang, Buku saku yang berjudul "Pencegahan Cyber Bullying dan Etika Bermedia Sosial bagi Remaja" ini dibagikan kepada siswa sebagai panduan serta pengingat supaya mereka tetap aman dan viral menggunakan media social dan internet selama masa belajar di rumah, dan terbebas dari perilaku cyberbullying.

Para pengurus OSIS SMA Nasional Malang dipilih menjadi peserta kegiatan pengabdian ini dengan pertimbangan bahwa para pengurus OSIS dapat menjadi agen literasi digital di lingkungan sekolah mereka. Harapannya kelak mereka dapat menjadi role model teman-teman mereka dalam memberikan perilaku penggunaan media sosial yang aman dan tanpa cyberbullying.

\section{HASIL DAN PEMBAHASAN}

Penjabaran mengenai hasil pengabdian dijabarkan dalam tiga poin berikut.

\section{a. Persiapan pelaksanaan pelatihan}

Tahap pertama dilakukannya Pengabdian Masyarakat ini adalah melakukan komunikasi kepada mitra yaitu SMA Nasional Malang. Tujuan dilakukannya komunikasi adalah memberikan gambaran kepada mitra mengenai kegiatan seperti apa yang akan dilakukan, serta apa saja yang perlu dipersiapkan. Tim pengabdian juga dapat mendata materi dan penyuluhan seperti apakah yang cocok diberikan kepada siswa-siswa SMA Nasional Malang. Dari tahap persiapan ini didapatkan hasil bahwa kegiatan pengabdian hanya akan diisi oleh 20 siswa dikarenakan kondisi pandemi dan rangkaian kegiatan harus dilakukan sesuai dengan protocol kesehatan yang ditetapkan oleh Pemerintah Kota Malang yaitu menjaga jarak, mengenakan masker serta mempersingkat durasi kegiatan. Peserta kegiatan diputuskan bersama adalah para pengurus OSIS SMA Nasional Malang yang ditunjuk langsung oleh Bagian Kesiswaan untuk mengikuti acara ini.

Terdapat beberapa faktor pendukung dari kegiatan ini, salah satunya adalah sambutan yang sangat hangat dari pihak mitra yaitu SMA Nasional Malang. Pihak mitra sangat membantu terselenggaranya pengabdian ini dengan lancar. Beberapa guru SMA Nasional Malang termasuk Wakil Kepala Sekolah juga turut mendampingi pengurus OSIS selama kegiatan penyuluhan berlangsung. Dalam cyberbullying sendiri, sekolah memiliki peranan yang sangat besar. (Washington, 2015) menyarankan selain peranan orangtua, sekolah dan guru juga memiliki peranan yang sama besarnya untuk mencegah terjadinya perilau cyberbullying. Terlebih lagi di 
masa Belajar Dari Rumah para siswa lebih banyak menghabiskan waktu mereka di rumah dengan menggunakan internet.

\section{b. Pelaksanaan pelatihan}

Perkembangan teknologi komunikasi dewasa ini semakin memudahkan setiap individu untuk melakukan pekerjaan sehari-hari, tak terkecuali para pelajar. Dengan program Belajar Dari Rumah yang dihimbau oleh Kemendikbud, para pelajar di Indonesia saat ini mau tak mau menghabiskan waktu lebih banyak menggunakan perangkat komunikasi hingga internet untuk kelancaran proses pembelajaran. Pola kegiatan belajar seperti ini tentunya membawa perubahan kepada para pelajar di Indonesia. Dengan meningkatnya kebutuhan akses internet, maka semakin besar pula peluang mereka untuk menggunakan internet sekaligus media sosial setiap harinya.

Media sosial merupakan jejaring sosial yang dapat mengintegrasikan setiap individu dengan konten-konten visual lainnya seperti foto, video, serta informasi lainnya melalui jaringan tertentu (Siddiqui \& Singh, 2016). Ketika media sosial membuat sebuah hubungan antara manusia dan teknologi, maka terciptalah ruang untuk membangun dan menjaga hubungan dengan orang lain. Sehingga dalam penggunaannya yang menjadi pengontrol utama adalah individunya, bukan teknologinya. (Maulida et al., 2020). (Freberg, 2018) mengatakan bahwa setiap individu yang menggunakan internet harus memahami apa saja batasan-batasan yang harus dilakukan supaya kegiatannya di internet tidak merugikan orang lain. Tindakan-tindakan seperti meninggalkan komentar buruk di media sosial, mengirimkan gambar yang tidak senonoh ke lawan jenis melalui media sosial, serta tidak menghiraukan teman di Grup WhatsApp maupun media sosial termasuk dalam perilaku cyberbullying

Dalam data penelitian (We Are Social, 2019) menyatakan bahwa rata-rata masyarakat Indonesia menghabiskan waktunya selama 3 jam 26 menit untuk mengakses media sosial. Sementara total pengguna aktif media sosial sebanyak 160 juta jiwa atau $59 \%$ dari total penduduk di Indonesia. Data ini sesuai dengan kondisi pengurus OSIS di SMA Nasional Malang di mana seluruh peserta pengabdian menyatakan memiliki media sosial pribadi dan mampu mengoperasikannya tanpa bantuan siapapun. Ini berarti para peserta pengabdian memiliki tingkat pemahaman teknologi yang tinggi. Sementara, 10 orang dari 20 peserta mengaku pernah mendapatkan perilaku cyberbullying seperti mendapatkan komentar yang tidak menyenangkan di media sosial. Maka dalam penyuluhan ini mitra diberikan dua materi. Materi pertama mengenai "Apa itu Cyberbullying? Bagaimana cara kita mengatasinya", dan materi kedua mengenai "Etika Bermedia Sosial"

Dalam pemaparan materi pertama, mita mendapatkan pemahaman bagaimana cyberbullying terkadang lebih berbahaya dibandingkan bullying pada umumnya. Pelaku cyberbullying dapat menggunakan nama anonim dan melakukan perisakan kepada korban melalui internet maupun media sosial sehingga meneror kehidupan pribadi mereka. Pelaku cyberbullying tudak melihat efek negatif yang menjadi penyebabnya, namun efek akan terlihat secara psikologis dan sosial dan dunia nyata. (Syah \& Istiana, 2018), Kegiatan ini didukung oleh partisipasi peserta yang berani mengungkapkan pengalaman mereka menjadi korban cyberbullying. Peserta mengaku pernah mendapatkan komentar negatif di media sosial, hingga tidak dimasukkan ke dalam suatu grup WhatsApp tertentu oleh teman mereka. 


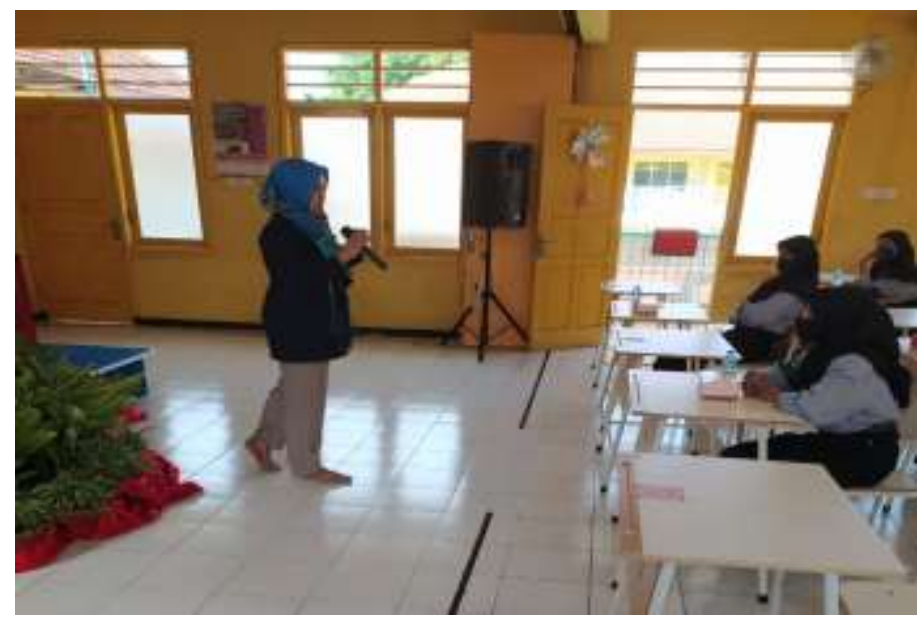

Gambar 1. Pemberian materi mengenai cyberbullying dan bagaimana cara mengatasinya

Dewasa ini sebagian besar sekolah di Indonesia tidak melarang siswa-siswanya menggunakan media sosial. Begitu juga dengan SMA Nasional Malang. Terlebih lagi saat ini banyak sekali materi penunjang pembelajaran yang tersedia melalui aplikasi di gawai maupun internet. Ketika penyampaian materi pertama mengenai "Apa itu Cyberbullying dan Bagaimana Kita Mencegahnya", guru-guru di SMA Nasional malang tidak ragu membagikan pengalaman mereka ketika memantau penggunaan media sosial siswa-siswanya. Ibu Agustin selaku Humas sekaligus Wakil Kepala Sekolah SMA Nasional Malang menyatakan bahwa beliau dan beberapa guru lainnya masih menyempatkan waktu untuk melihat unggahan siswa-siswanya di media sosial. Mereka juga tidak ragu untuk langsung menegur siswa apabila ada unggahan yang dirasa tidak pantas, terlebih lagi jika menyangkut nama sekolah.

Peran guru sangatlah penting untuk pencegahan cyberbullying. Penelitian (Glasner, 2010) menyebutkan bahwa selain orangtua, guru memiliki peran yang sangat penting untuk mencegah perilaku cyberbullying karena terkadang prangtua mengabaikan dan tidak sadar akan masalah cyberbullying. Maka guru haruslah menjadi tempat yang aman, sehingga siswa dapat berkonsultasi atau melaporkan jika mereka menjadi korban cyberbullying. Pada materi pertama ini juga disampaikan kepada para pengurus OSIS SMA Nasional Malang untuk mencari "safe place" seperti sahabat terdekat maupun guru di sekolah jika mereka menjadi korban cyberbullying. Karena cyberbullying membawa dampak yang sangat besar apabila tidak segera ditangani dan dapat menimbulkan kecemasan sosial, depresi, hingga bunuh diri.

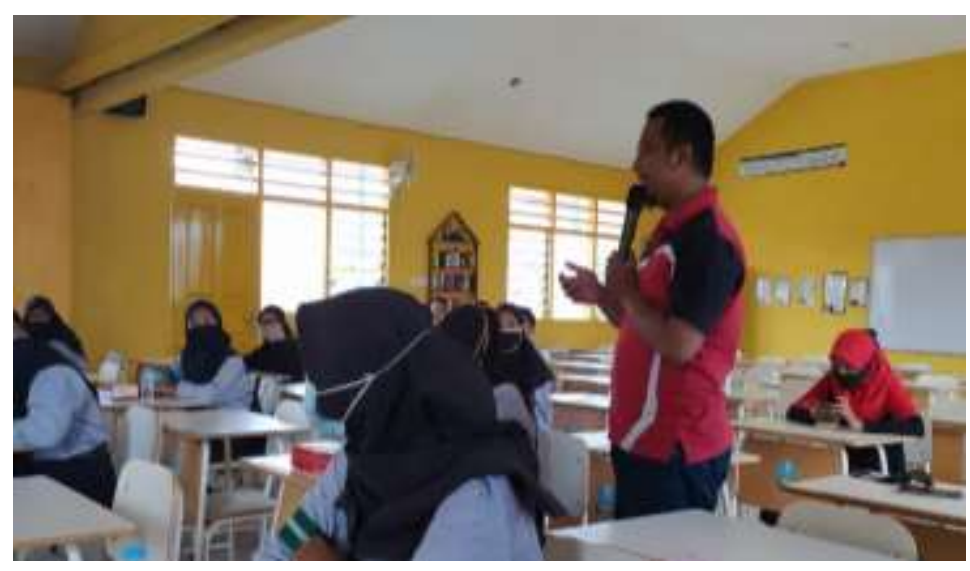

Gambar 2. Salah satu guru SMA Nasional Malang turut berpartisipasi dalam diskusi mengenai peran guru dalam pencegahan cyberbullying 
Setelah mendapatkan paparan mengenai cyberbullying, peserta pengabdian mendapatkan materi kedua yaitu mengenai "Literasi Media dan Etika Bermedia Sosial". Meskipun tingkat penggunaan teknologi pengurus OSIS SMA Nasional tinggi, namun ternyata mereka belum memiliki pemahaman yang mumpuni mengenai etika bermedia sosial. Terbukti ketika pemateri menyampaikan pertanyaan di awal dan 15 dari 20 siswa menyatakan tidak mengetahui bagaimana cara beretika yang baik di media sosial.

Penelitian (Whittaker \& Kowalski, 2015) menunjukkan bahwa para remaja yang duduk di bangku sekolah notabene lebih mudah untuk melakukan pelanggaran beretika dalam penggunaan internet maupun media sosial. Pelanggaran etika inilah yang dapat memberikan dampak buruk seperti membahayakan perkembangan mental baik secara individu maupun sosial.

Selain belum memahami etika dalam bermedia sosial, sebagian peserta juga tidak memahami regulasi hukum seperti Undang Undang tentang Informasi dan Transaksi Elektronik (UU ITE) yang mengatur mengenai segala bidang dalam pengaturan serta pemanfaatan Teknologi Informasi dan Transaksi Elektronik. Pada pemaparan materi kedua, pemateri menyisipkan informasi kepada peserta bahwa ada beberapa perilaku cyberbullying yang dapat membuat pelaku terjerat UU ITE seperti meninggalkan kata-kata yang tidak menyenangkan pada kolom komentar, membagikan foto yang tidak pantas, mengungah foto maupun video yang melanggar norma dan tidak melalui persetujuan pemilik media, serta penyebaran berita hoax.

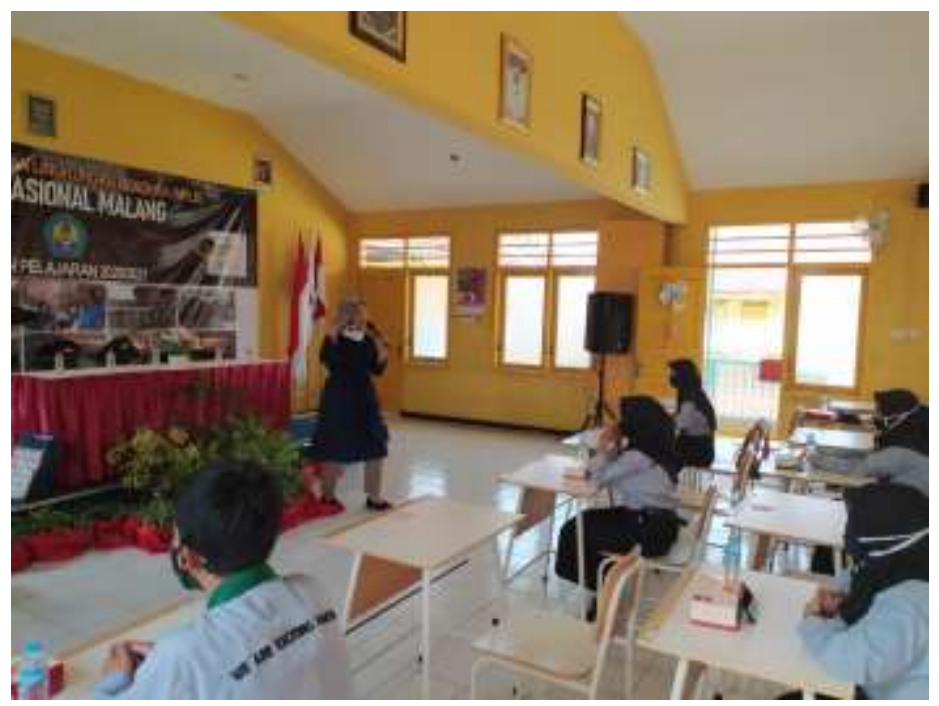

Gambar 3. Pemberian materi mengenai Literasi Medi dan Etika Bermedia Sosial

Maka untuk tetap dapat menggunakan media sosial secara aman, peserta mendapatkan informasi mengenai berpikir kritis dalam bermedia sosial. Dengan berpikir kritis, para peserta didorong untuk tidak mengambil sembarangan informasi yang tersedia di internet. Para peserta juga mendapatkan poin penting mengenai apa yang seharusnya dipikirkan sebelum mengunggah konten di media sosial, seperti: 1) Siapa saja yang akan melihat, 2) Apakah keamananku terjamin, 3) Adakah pihak yang diruhikan, 4) Apakah saya benar-benar perlu mengunggah ini, 5) Apakah semua pihak dapat menerima unggahan saya di media sosial?, 6) Apakah konten saya di media sosial mengandung unsur SARA? ,7) Sudah siapkah saya jika ada pihak yang tidak senang dengan konten saya di media sosial?, 8) Apakah sumber informasi yang saya dapatkan dari internet terpercaya?, 9)Apakah sekiranya nilai dan sudut pandang orangyang melihat ini sama dengan sudut pandang saya.

Setelah mendapatkan informasi mengenai Sembilan tahap berpikir kritis dalam menggunakan media sosial, peserta diminta untuk dapat langsung mempraktekannya di media sosial maupun grup WhatsApp mereka. Berdasarkan pengakuan para peserta, mereka memiliki keseragaman dalam penggunaan platform media sosial. Tiga platform media sosial yang paling dugunakan oleh peserta adalah WhatsApp, Instagram, dan Youtube. Data ini selaras dengan hasil 
survey (We Are Social, 2019) mengenai jenis media sosial yang paling sering digunakan di Indonesia. Lima peringkat pertama ditempati oleh YouTube, WhatsApp, facebook, Instagram, dan Twitter. Melalui platform inilah para pelajar aktif dan menghabiskan waktu mereka. Serta melalui platform ini juga siswa memiliki kesempatan untuk mendapatkan atau bahkan menjadi pelaku cyberbullying.

\section{Media Sosial yang Paling Sering Digunakan di Indonesia}

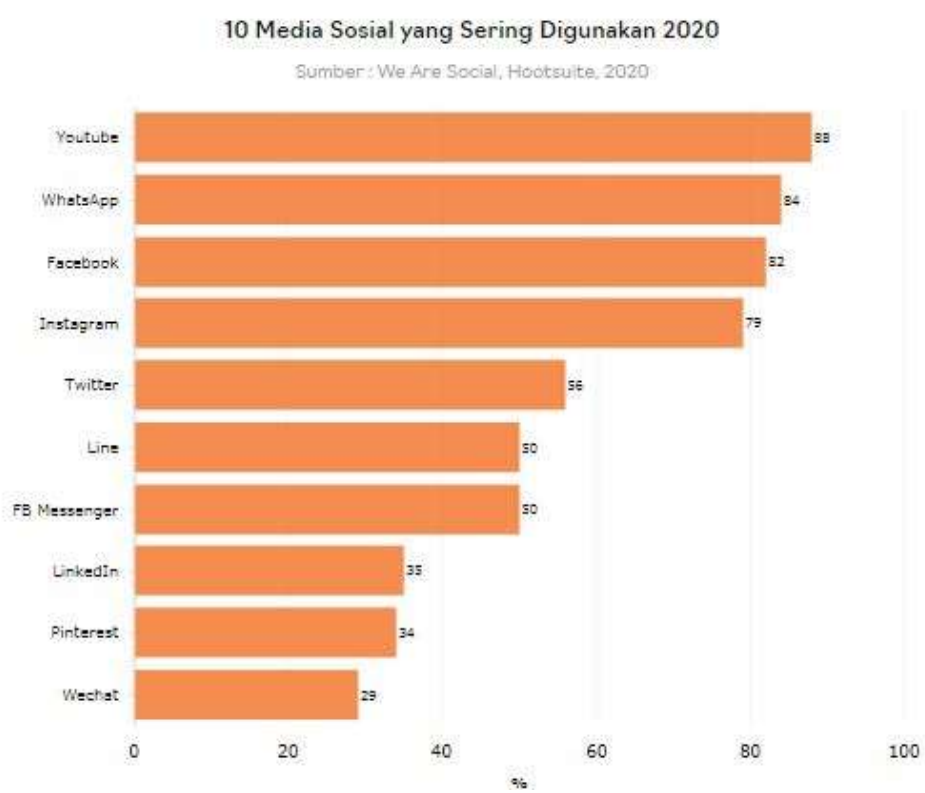

Gambar 4. Media Sosial yang paling sering digunakan di Indonesia sepanjang tahun 2020

Salah satu cara untuk menghindari pelajar menjadi korban maupun pelaku cyberbullying adalah dengan tidak mengunggah konten terlalu sering di media sosial. Apapun yang diunggah di media sosial tentunya memiliki pro dan kontra. Mengunggah konten di media sosial terlalu sering dapat mengganggu orang lain dan memancing perilaku cyberbullying. Semakin banyak teman di media sosial, maka individu tersebut harus pula bersiap-siap dengan banyaknya komentar yang datang (Syah \& Istiana, 2018). Oleh karena itu batasan-batasan seperti etika dalam bermedia sosial serta kemampuan berpikir kritis perlu dimiliki oleh para siswa untuk membentengi diri mereka dari kemungkinan terjadinya perilaku cyberbullying.

\section{c. Evaluasi: Pre-test dan post-test}

Tahap kegiatan terakhir dari pengabdian kepada mitra adalah evaluasi. Evaluasi dilakukan dengan melakukan pre-test di awal kegiatan, serta post-test di akhir kegiatan. Pada pretest didapati hasil bahwa sebanyak 20 peserta pengabdian tidak memahami apa itu cyberbullying, dan 18 peserta tidak memahami bagaimana cara beretika bermedia sosial yang baik. Sementara hasil dari post-test menunjukkan perubahan yang cukup signifikan. Setelah mendapatkan materi mengenai cyberbullying dan Literasi Media Sosial, terdapat peningkatan bahwa 18 peserta telah memahami apa itu cyberbullying, serta 20 peserta memahami bagaimana cara beretika bermedia sosial yang baik. Gambar di bawah merupakan analisis terhadap dampak edukasi yang diberikan kepada mitra. Para peserta pengabdian serta jajaran guru SMA Nasional malang juga menyatakan $100 \%$ setuju apabila pelatihan ini sangat bermanfaat dalam menjaga para siswa SMA Nasional Malang untuk terhindar dari perilaku cyberbullying di masa Belajar dari Rumah. 


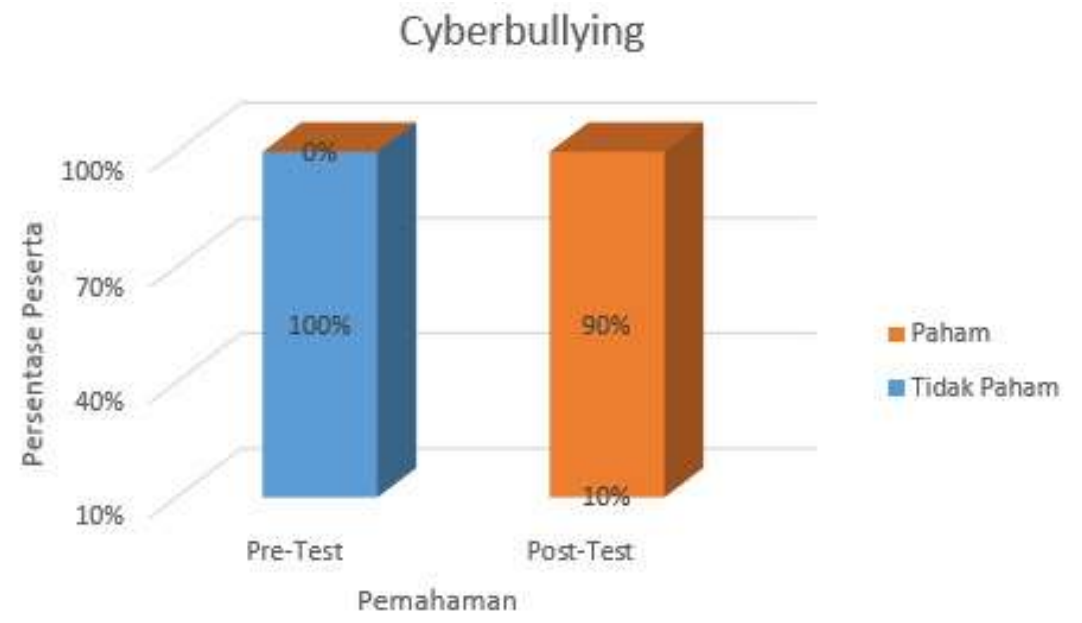

Gambar 4. Grafik perbedaan pemahaman materi cyberbullying dalam pre-test dan post-test

\section{Etika Bermedia Sosial}

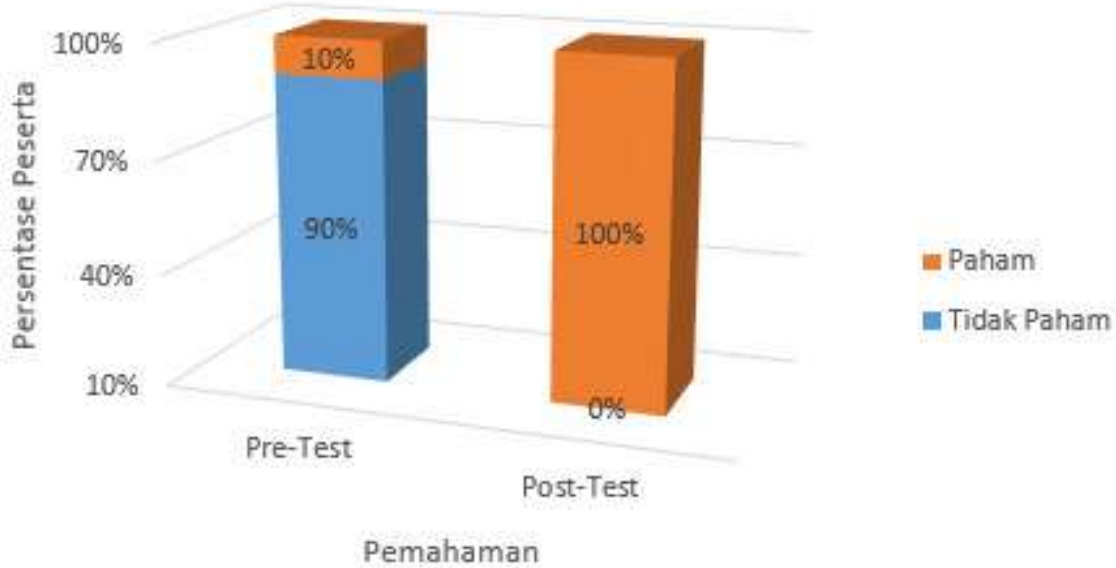

Gambar 5. Grafik perbedaan pemahaman materi "Etika Bermedia Sosial” dalam pre-test dan "post-test"

Kegiatan terakhir adalah membagikan buku saku berjudul "Pencegahan Cyberbullying dan Etika Bermedia Sosial bagi Remaja". Buku saku ini dibagikan kepada seluruh mitra berikut juga kepada guru SMA Nasional Malang yang hadir di saat pengabdian. Buku saku yang diberikan akan dijadikan rujukan oleh pengurus OSIS SMA Nasional Malang untuk mengedukasi literasi media kepada teman-teman sebaya mereka di sekolah. Dalam buku saku yang dibagikan terdapat penjelasan mengenai cyberbullying, bentuk-bentuk kegiatan yang merupakan cyberbullying, dampak cyberbullying, cara menghentikan cyberbullying, berpikir kritis dalam bermedia sosial, serta cara menjaga keamanan dan data diri ketika menggunakan internet. 


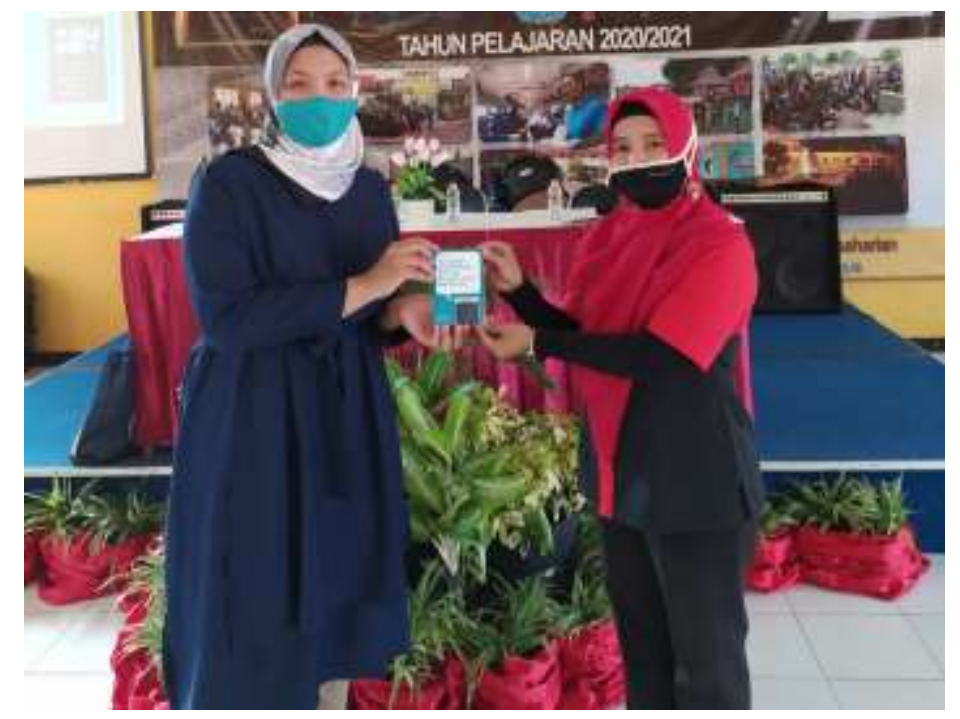

Gambar 6. Pembagian buku saku "Pencegahan Cyberbullying dan Etika Bermedia Sosial bagi Remaja" diwakilkan oleh Wakil Kepala Sekolah SMA Nasional Malang

\section{KESIMPULAN}

Kegiatan pengabdian kepada masyarakat tentang Edukasi Literasi Media Sosial Untuk Pencegahan Cyberbullying telah terlaksana dengan baik serta mendapatkan respon dan umpan balik yang sangat baik dari jajaran guru serta pengurus OSIS SMA Nasional Malang. Hal ini terlihat dari evaluasi berupa hasil post-test yang memiliki kenaikan sangat signifikan dibandingkan pemahaman mengenai cyberbullying dan literasi media ketika pre-test. Hasil yang diperoleh dari pengabdian ini adalah:

1. Peserta memahami apa itu cyberbullying, bentuk-bentuk cyberbullying, serta bagaimana cara mengatasinya.

2. Peserta memahami bagaimana beretika dalam bermedia sosial dan memiliki cara berpikir kritis ketika mengunggah suatu konten maupun komentar di media sosial.

3. Guru SMA Nasional Malang memahami bahwa mereka memiliki peran yang penting untuk menjadi tempat aman bagi siswa ketika ada salah satu siswa menjadi korban cyberbullying.

Kegiatan pengabdian ini juga memiliki beberapa keterbatasan, salah satunya adalah kegiatan ini dilakukan di masa pandemi dan harus tetap terlaksana dengan mematuhi protokol kesehatan. Dengan begitu pengabdian tidak dapat dilakukan dengan mengumpulkan banyak peserta dan hanya 20 peserta yang dapat bergabung, serta kegiatan pengabdian hanya dapat dilakukan selama 45 menit. Metode penyajian materi juga hanya dapat diberikan dalam bentuk pemaparan materi tanpa ada games sesi diskusi kelompok, maupun FGD untuk tetap menjaga jarak antar peserta.

Terdapat beberapa kemungkinan pengembangan dari kegiatan pengabdian ini. Salah satunya adalah merancang modul mengenai cyberbullying yang khusus ditunjukkan untuk guruguru baik di tingkat SD maupun tingkat SMA. Mengingat saat ini hampir seluruh siswa dari SD hingga SMA memiliki gawai, terutama di kota-kota besar seperti Malang. Modul mengenai cyberbullying ini kelak dapat dipahami oleh guru agar guru yang bertanggung jawab di lingkup sekolah tidak abai dengan kemungkinan adanya perilaku cyberbullying yang dilakukan oleh siswanya, serta memberikan bekal kepada guru untuk menangani kasus cyberbullying secara lebih serius. 


\section{UCAPAN TERIMA KASIH}

Penulis mengucapkan terima kasih kepada Fakultas Ilmu Sosial Universitas Negeri Malang yang telah memberi dukungan financial terhadap pengabdian ini.

\section{DAFTAR PUSTAKA}

Candrasari, Y., \& Claretta, D. (2020). Pengembangan Dan Pendampingan Literasi Digital Untuk Peningkatan Kualitas Remaja Dalam Menggunakan Internet. 4(4), 611-618.

Dipo, M., \& Samsudin, I. (2016). Pengaruh Pembelajaran Model Observasi Lapangan (Outdoor Study) dan Pembelajaran Inquiry Terhadap Hasil Belajar Mata Pelajaran Sosiologi Siswa IPS SMA Negeri 3 Probolinggo. Jurnal Penelitian Dan Pendidikan IPS (JPPI), 10(2), 261-276.

Farge, E. (2020). Children at risk as pandemic pushes them online, warns U.N. agency. https://www.reuters.com/article/us-healthcare-coronavirus-technology/children-at-riskas-pandemic-pushes-them-online-warns-u-n-agency-idUSKBN22H2EZ

Freberg, K. (2018). Social Media for Strategic Communication: Creative Strategies and ResearchBased Applications. SAGE Publications.

Glasner. (2010). On the Front Lines: Educating Teachers about Bullying and Prevention Methods. Journal of Social Sciences, 6(4), 537-541. https://doi.org/10.3844/jssp.2010.537.541

Kurniawati, J., \& Baroroh, S. (2016). Literasi Media Digital Mahasiswa Universitas Muhammadiyah $\begin{array}{llll}\text { Bengkulu. Jurnal } & \text { Komunikator, }\end{array}$ http://journal.umy.ac.id/index.php/jkm/article/view/2069

Malihah, Z., \& Alfiasari, A. (2018). Perilaku Cyberbullying pada Remaja dan Kaitannya dengan Kontrol Diri dan Komunikasi Orang Tua. Jurnal Ilmu Keluarga Dan Konsumen, 11(2), 145-156. https://doi.org/10.24156/jikk.2018.11.2.145

Maulida, H., Prawira, Y., \& Nugrahenti, M. C. (2020). Edukasi Hukum Dan Etika Bermedia Sosial Bagi Gen Z. Amal Ilmiah: Jurnal Pengabdian Kepada Masyarakat, 1(2), 115-122. https://doi.org/http://dx.doi.org/10.36709/amalilmiah.v1i2.11867

Sartana, \& Afriyeni, N. (2017). Perilaku Perundung Maya (Cyber Bullying) Pada Remaja Awal. Journal Psikologis Insight, 1(1), 25-39. https://ejournal.upi.edu/index.php/insight/article/download/8442/5299

Siddiqui, S., \& Singh, T. (2016). Social Media its Impact with Positive and Negative Aspects. International Journal of Computer Applications Technology and Research, 5(2), 71-75. https://doi.org/10.7753/IJCATR0502.1006

Syah, R., \& Istiana, H. (2018). Upaya pencegahan kasus cyberbullying bagi remaja pengguna media sosial di indonesia. Jurnal Penelitian Kesejahteraan Sosial, 17 no 2(2), 131-146. https://www.elearningkebencanaan.education/longsor/upaya-pencegahan-longsor/

Washington, E. (2015). An Overview of Cyberbullying in Higher Education. Adult Learning, 26, 2127. https://doi.org/10.1177/1045159514558412

We Are Social. (2019). WAS_ThinkForward_2020. 31-54. https://wearesocialnet.s3.amazonaws.com/uk/wpcontent/uploads/sites/2/2019/11/WAS_ThinkForward_2020.pdf

Whittaker, E., \& Kowalski, R. M. (2015). Cyberbullying Via Social Media. Journal of School Violence, 14(1), 11-29. https://doi.org/10.1080/15388220.2014.949377 